\title{
PEMBENTUKAN IKLIM SOSIAL-AKADEMIK DI ASRAMA MAHASISWA
}

\author{
Rahmania Utari, Mada Sutapa, Tina Rahmawati \\ FIP Universitas Negeri Yogyakarta \\ email: rahmania_utari@uny.ac.id
}

\begin{abstract}
Abstrak: Pembentukan Iklim Sosial-Akademik di Asrama Mahasiswa. Penelitian ini bertujuan untuk mendeskripsikan pembentukan iklim sosialakademik di Asrama Mahasiswa FIP UNY. Penelitian ini menggunakan pendekatan kualitatif berupa prototipe model pembentukan iklim sosial-akademik yang dapat dikembangkan secara fleksibel oleh pengelola layanan akomodasi bagi mahasiswa. Hasil penelitian memperlihatkan bahwa iklim sosial akademik di kedua setting penelitian secara umum dipersepsikan positif atau baik oleh para penghuninya. Meskipun dengan demikian pada kasus kedua ditemukan catatan khusus berkaitan dengan fasilitas, interaksi lintas budaya, dan sistem pembinaan serta pengasuh. Selain itu upaya pengelola rumah susun mahasiswa di kedua setting telah mengarah pada pembentukan iklim sosial akademik namun masih perlu dipertajam. Adapun aspek-aspek yang menjadi tinjauan dalam model pengembangan iklim sosial-akademik di rumah susun mahasiswa meliputi penghuni, pengasuh, sistem pembinaan, fasilitas dan organisasi.
\end{abstract}

Kata kunci: manajemen pendidikan tinggi, manajemen peserta didik, asrama mahasiswa

\begin{abstract}
Establishment of Social-Academic Climate in Student Dormitory. This study aims to describe the establishment of the social-academic climate in the student dormitory of fip uny. this study used a qualitative research approach which produced a prototype model of establishment of the social-academic climate that can be developed flexibly by the management services for student accommodation. the results showed that the social climate in the second academic research setting is generally perceived as positive or good by the residents. nevertheless, in the second case found a particular note with regard to facilities, cross-cultural interaction, and guidance system as well as the caregiver. in addition, the student dormitory manager efforts have led to the establishment of academic social climate in the both set but still need to be sharpened. the aspects which became review the model of development of social-academic climate in the student dormitory are residents, caregivers, guidance systems, facilities and organizations.
\end{abstract}

Keywords: higher education management, student management, the student dormitory

\section{PENDAHULUAN}

Salah satu bentuk layanan perguruan tinggi kepada mahasiswa adalah sarana asrama. Hunian adalah persoalan yang berkaitan dengan kebutuhan dasar manusia, tidak terkecuali kalangan mahasiswa. Beberapa perguruan tinggi negeri dan swasta memperoleh hibah dari Kemenpera berupa pembangunan rumah susun mahasiswa sejak tahun 2008. Tujuan penyelenggaraan rumah susun mahasiswa adalah untuk menunjang kegiatan belajar mahasiswa terutama bagi mahasiswa yang berasal dari luar kota. Araujo dan Murray (2010) dalam hasil penelitiannya memperlihatkan secara rata-rata mahasiswa yang tinggal di asrama mencapai Indeks prestasi rata- 
rata lebih tinggi 0,19 sampai dengan 0,97 dibanding dengan mereka yang tinggal jauh dari kampus. Penelitian terdahulu sebagaimana dikutip Bozick (2007) menemukan fakta-fakta antara lain bahwa mahasiswa yang tinggal di dekat kampus akan sering melakukan kontak dengan teman sebayanya, dosen dan staf lain daripada mahasiswa yang tinggal di rumah atau jauh dari kampus. Mahasiswa yang berada dekat kampus secara otomatis lebih mudah mengakses fasilitas kampus lainnya sehingga lebih mudah mendapatkan dukungan terhadap prestasi belajar. Hal tersebut senada dengan pendapat Sururi dan Nasihin (2009:222) bahwa manfaat asrama bagi peserta didik yaitu: 1) tugas sekolah dapat dikerjakan dengan cepat dan sebaik-baiknya terutama jika berbentuk tugas kelompok; 2) sikap dan tingkah laku peserta didik dapat diawasi oleh petugas asrama dan pendidik; 3) jika diantara peserta didik mempunyai kesulitan (kiriman dari orang tua terlambat, sakit, dsb) dapat saling membantu; 4) meringankan kecemasan orang tua terhadap putraputrinya; 5) dapat juga merupakan salah satu cara untuk mengendalikan tingkah laku remaja yang kurang baik (negatif). Dalam penelitiannya Bozick (2007) merekomendasikan agar mahasiswa khususnya di tahun pertama dapat hidup dekat dengan lingkungan kampus dalam hal ini difasilitasi asrama kampus, karena mampu mengembangkan komitmen akademik mereka dan komunikasi dengan warga kampus lainnya.

Penelitian yang dilakukan Rodger dan Johnson (2005) menunjukkan mahasiswa yang tinggal di asrama besar seperti rumah susun beresiko mengalami rasa terasing dibanding dengan mereka yang hidup di asrama seperti kos. Beberapa perguruan tinggi di Indonesia sendiri mengatur bahwa mahasiswa yang dapat tinggal di rumah susun mahasiswa adalah hanya mahasiswa tahun pertama. Mahasiswa pada tahun pertama tersebut harus mengalami penyesuaian diri baik secara sosial maupun akademik. Hal ini ditambah dengan situasi lingkungan rumah susun yang berbeda dengan lingkungan tempat tinggal mereka sebelumnya secara umum.

Beberapa perguruan tinggi di DIY telah dilengkapi dengan sarana asrama berupa rumah susun, di antaranya UNY dan UMY. Untuk mengoptimalkan manfaat fasilitas rumah susun mahasiswa, diperlukan langkah-langkah pembinaan agar atmosfer yang ada sejalan dengan kebutuhan mahasiswa. Penelitian ini bertujuan untuk mengungkap bagaimana iklim sosial-akademik yang ada, upaya apa saja yang dilakukan oleh pengelola untuk membentuk iklim sosial-akademik di dua rumah susun mahasiswa (UNY dan UMY), dan aspek-aspek saja yang perlu diperhatikan dalam pengembangan iklim sosial-akademik di rumah susun mahasiswa.

\section{METODE}

Penelitian ini didesain pada dua situs penelitian, yaitu rumah susun mahasiswa A dan B yang masing-masing berlokasi di Propinsi DIY. Penunjukkan dua kasus atau lebih pada penelitian kualitatif dikenal sebagai studi multi kasus. Bogdan dan Biklen (1998:62) menyatakan jika penelitian dilakukan di dua atau lebih subyek, latar, atau tempat penyimpanan data, maka disebut sebagai studi multi kasus.

Peneliti hadir pada setting penelitian dan berinteraksi langsung dengan sumber data. Penggunaan peneliti sebagai key instrument didasarkan pada karakter penelitian kualitatif itu sendiri yang antara lain hermeneutik, dan mengandung interaksi simbolik (Sutopo, 2002:28). Subjek penelitian adalah para penghuni rumah susun mahasiswa di kedua lokasi beserta unsur pengelola di masingmasing rumah susun tersebut. Adapun teknik pengumpulan data yang digunakan 
meliputi observasi, angket, wawancara, dan focussed group discussion, serta studi dokumentasi. Kehadiran peneliti akan diketahui oleh informan, dan bersifat observative participant/passive participant.

Mengadopsi dari desain metode studi kasus yang dikemukakan Yin (1995:61), alur analisis data penelitian secara keseluruhan dapat dilihat pada Gambar 1.

\section{HASIL DAN PEMBAHASAN \\ Iklim Sosial-Akademik pada Rumah Susun Mahasiswa}

Menurut Schneider dan Hall (1972) dalam Kundu (2007:104), iklim organisasi laksana kesimpulan dari sebuah evaluasi yang didasarkan oleh berbagai tindakan dan persepsi tentang peristiwa-peristiwa yang ada. Dengan kata lain, iklim organisasi adalah hasil total antara persepsi individu dan lingkungan organisasi. Secara umum mahasiswa penghuni rusunawa kampus A maupun B memiliki persepsi positif tentang iklim sosial-akademik di tempatnya masing-masing. Sejumlah 132 responden di dua situs penelitian memberikan opininya melalui angket terbuka tentang iklim yang dirasakan di masing-masing rumah susun mahasiswa. Mayoritas mahasiswa menilai rumah susun mahasiswa yang ditempatinya nyaman, meskipun masih ada beberapa catatan khusus yang meliputi segi interaksi, fasilitas belajar, pembinaan dan pengasuh. Data angket hanya digunakan sebagai data awal, untuk selanjutnya dikembangkan peneliti untuk mengungkapkan lebih jauh melalui wawancara dan FGD.

Hasil angket, wawancara dan FGD menunjukkan banyak hal positif yang di-rasakan mahasiswa selama mereka tinggal di asrama mahasiswa baik tentang kekerabatan, rasa kekeluargaan, rasa kebersamaan, pergaulan mengenal mahasiswa dari beragam budaya dan daerah, maupun karena ragamnya kegiatan, pelayanan pengasuh dan fasilitas. Resiko hidup dalam rumah susun rasa berupa rumah sesak akibat terlalu banyaknya interaksi sebagaimana disampaikan Elvia (2011) tidak dirasakan oleh para mahasiswa.

Mahasiswa baru penghuni asrama sebagian besar mengaku memerlukan waktu untuk adaptasi merasakan ke-

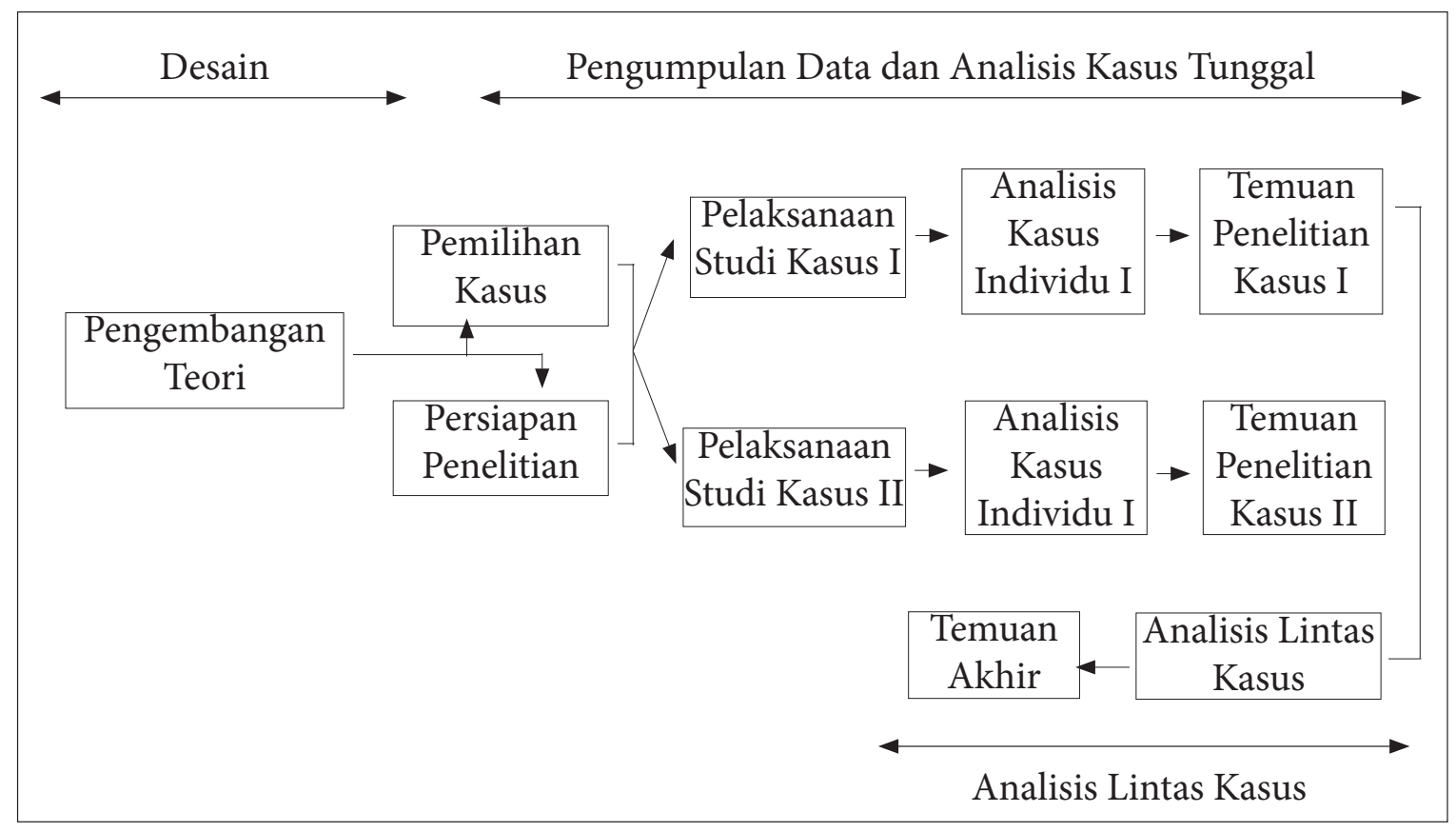

Gambar 1. Alur Proses dan Analisis Data Penelitian 
nyamanan dalam kehidupan tinggal di lingkungan asrama. Pola adaptasi tersebut mencakup lingkungan fisik asrama dan lingkungan sosial asrama. Hal tersebut sesuai dengan pendapat Semiawan (2009:91) bahwa ikatan sosial yang terjadi karena terpenuhinya rasa aman serta kemungkinan yang diberikan oleh lingkungan untuk pergi "menjelajahi lingkungan" merupakan dasar (fundamen) dari proses sosialisasi serta memiliki akibat dan dampak yang sangat khusus sifatnya terhadap perkembangan.

Fasilitas juga merupakan bagian dari lingkungan fisik pendukung kenyamanan penghuni asrama. Baik kampus A maupun B menyediakan ruang belajar dan sarana wi-fi yang langsung mendukung kegiatan akademik. Hanya saja untuk kampus B, desain bagian atap gedung asrama yang terbuka bagian tepi koridornya, membuat hewan dari luar seperti burung masuk dan mengotori bagian dalam asrama. Hal tersebut memang dikeluhkan penghuni dan membuat tidak nyaman karena kotor dan bau di koridor lorong depan kamar, walaupun petugas kebersihan sudah rutin membersihkan kotoran di koridor lorong depan kamar penghuni seminggu sekali.

Dibandingkan rusunawa kampus A, kamar di kampus B memang tidak terlalu luas, setiap kamar dihuni oleh 3 mahasiswa, dengan tersedia juga meja, almari, kasur dan kursi. Suasana koridor atau lorong depan kamar dalam keseharian terlihat sangat padat diisi dengan barang-barang pribadi mahasiswa dan kadangkala juga sebagai tempat jemuran pakaian mahasiswa. Hal tersebut memang membuat tidak nyaman karena privasi penghuni menjadi terganggu, walaupun terdapat peraturan yang mengharuskan menjaga kebersihan dan kenyamanan bersama. Untuk kampus B, ruang terbuka bersama berada di setiap pertemuan blok dalam satu lantai, dan di lantai bawah gedung asrama. Ruang terbuka tersebut sangat mendukung juga sebagai atmosfer bersosialisasi antar mahasiswa penghuni sekaligus ruang belajar bersama. Ruang bersama juga dilengkapi oleh jaringan wifi, dengan akses yang menggunakan sistem kuota dan filter terhadap jaringan media sosial pada hari dan jam efektif belajar.

Meninjau kajian arsitektural di atas, bangunan rusunawa kampus A condong menggunakan point block, sedangkan desain kampus B menggunakan central corridor system. Desain point block memiliki banyak keuntungan karena core yang tersentral di masing-masing lantai memungkinkan penghuni melakukan aktivitas bersama-sama di satu kesempatan. Dari segi estetika juga desain point block lebih menarik dibanding central corridor system karena koridor lebih pendek. Hanya saja, biaya pembangunan dengan desain point block lebih tinggi. Dari sisi pembentukan iklim sosial-akademik hal ini memberi pengaruh pada interaksi penghuni khususnya dalam memanfaatkan zona publik.

Permasalahan interaksi penghuni bukan sekedar dipengaruhi oleh lay out bangunan, namun juga keberagaman latar belakang penghuni. Keberagaman seperti budaya, bahasa, agama, ini bisa memberikan warna berbeda di asrama. Pada kampus A, keragaman asal penghuni tidak hanya berasal dari dalam negeri namun juga mahasiswa asing dari Thailand, Filipina, Malaysia dan RRC. Perilaku yang sering muncul dari mahasiswa asing penghuni asrama adalah sikap malumalu yang menyebabkan mereka masih enggan bergaul, dan ketidakmampuan mereka dalam menggunakan bahasa Indonesia maupun bahasa Inggris yang menyebabkan mereka belum bisa bersosialisasi. Pada kampus B, mahasiswa yang berasal dari luar Jawa menunjukkan ingin bisa beradaptasi dengan lingkungan sekitar, khususnya dalam aspek bahasa Jawa, mengingat bahasa Jawa menjadi alat 
komunikasi utama keseharian masyarakat sekitar dan di sekolah-sekolah tempat mahasiswa asrama praktek mengajar.

Berdasarkan hasil temuan, faktor bahasa menjadi salah satu persoalan dalam interaksi antar penghuni. Faktor bahasa atau semantik menurut Gibson dkk (2004:428-429) adalah salah satu hambatan komunikasi. Penggunaan bahasa daerah terus-menerus di sebuah komunitas yang berada di tengah-tengah komunitas lainnya dapat menimbulkan kesalahpahaman karena komunitas lainnya merasa tidak dilibatkan atau merasa asing. Contoh sumber konflik lainnya adalah menyangkut kebiasaan salah satu komunitas di rumah susun yang berbicara dengan suara keras. Bagi kelompok lainnya, hal ini dianggap tidak wajar karena bersuara keras dinilai mengganggu atau tidak sopan. Padahal kebiasaan bersuara keras bagi kelompok pertama tidak dimaknai sebagai pelanggaran terhadap kesopanan.

Temuan konflik yang sifatnya keras sangat jarang ditemui di antara penghuni asrama. Konflik yang menonjol di antara penghuni asrama adalah karena perbedaan karakter mahasiswa. Upaya penyelesaian konflik dilakukan dengan menekankan rasa saling tenggang rasa satu sama lain. Di rusunawa kampus A penyelesaian konflik dilakukan oleh pengasuh mahasiswa senior yang berada di lorong setiap lantai gedung asrama, dan dilanjutkan di tingkat pengasuh asrama kalau konflik tetap tidak bisa diselesaikan dengan baik. Sistem pengasuhan berbasis lorong oleh pengasuh mahasiswa senior ternyata efektif untuk menangani konflik meskipun penyelesaian langsung oleh masing-masing individu yang terlibat konflik menjadi pilihan utama sebelum diintervensi oleh para pengasuh asrama.

Untuk kasus B, upaya penyelesaian konflik juga dilakukan dengan menekankan sikap saling menghargai dan senantiasa menanamkan senyum, sapa, santun kepada sesama penghuni asrama. Penyelesaian konflik diutamakan diselesaikan oleh masing-masing individu, baru kemudian diselesaikan oleh pengasuh mahasiswa apabila tidak ada titik temu. Namun perbedaan karakter dan budaya malah menimbulkan rasa kebersamaan dan pertemanan di antara mereka. Ada hal menarik, bahwa atmosfer toleransi bisa tercipta dari adanya rasa kebersamaan dan pertemanan walaupun berbeda budaya dan keyakinan. Seperti pengalaman mahasiswa beragama Islam dari propinsi NAD yang hidup satu kamar dengan mahasiswa dari propinsi NTT beragama Kristen, yang malah sering mengingatkan waktu sholat Maghrib.

Owens (1995:147) mendefinisikan konflik sebagai suatu hal yang mucul bila terdapat ketidaksesuaian atau pertentangan. Konflik antara individu dengan kelompok sering diwarnai oleh adanya tekanan kelompok terhadap individu bersangkutan. Tekanan ini boleh jadi muncul karena individu dianggap melanggar norma-norma kelompok seperti visi, misi, tujuan, sasaran, tindakan (Usman, 2004:224). Hal inilah yang dialami sebagian kecil mahasiswa di kasus B. Komunitas yang berasal dari luar Jawa dianggap oleh komunitas lain telah melanggar norma karena tolok ukur yang digunakan adalah tolok ukur kelompok lainnya tersebut. Namun demikian situasi ini tidak bermuara pada serangan, yang artinya masih dalam kadar konflik yang wajar.

Atmosfer sosial di rusunawa kampus $B$ terlihat dari rasa persaudaraan di antara komunitas berbasis program. Seperti ditunjukkan dengan keberadaan forum-forum kecil yang dibentuk dengan inisiatif penghuni sendiri. Forum-forum ini berkegiatan layaknya unit kegiatan mahasiswa, seperti bidang musik, olahraga, seni, dan keagamaan. Kegiatan forum-forum tersebut dikoordinasikan dengan kegiatan wajib dari pengelola 
asrama sebagai bentuk pembinaan mahasiswa berasrama. Pada rusunawa kampus A, kegiatan bagi penghuni asrama juga dikembangkan oleh pengelola asrama seperti sebuah unit kegiatan mahasiswa. Bedanya, kegiatan yang diberikan memang lebih banyak menekankan aktivitas keagamaan. Atmosfer religius seperti itu ternyata memberikan persepsi positif bagi penghuni rusunawa karena mereka jadi terbiasa dengan kehidupan tertib, baik, dan teratur dalam beribadah dan berbusana.

Mengenai iklim akademik khususnya atmosfer belajar, di rusunawa kampus $\mathrm{A}$ sangat tergantung pada individu masingmasing dalam membagi waktu antara kegiatan asrama dan belajar. Pihak asrama sendiri tetap memberikan kelonggaran waktu untuk para penghuni dalam membagi waktu beraktivitas dan belajar, yang mana waktu sangat luang disediakan sehabis sholat Isya. Untuk rusunawa kampus B, atmosfer belajar telah terbentuk dengan adanya jam belajar di asrama, dan hal ini cukup membantu menciptakan atmosfir yang kondusif untuk belajar, dan untuk mengendalikan mahasiswa agar menjaga ketenangan pada jam belajar. Hal yang menarik adalah terciptanya iklim saling menolong apabila mahasiswa lain mengalami kesulitan belajar. Mahasiswa membentuk kelompok-kelompok belajar, dan hal tersebut merupakan rasa kesadaran mereka untuk belajar bersama dengan mahasiswa lain. Terciptanya iklim sosial akademik di rusunawa melalui kegiatan kelompok komunitas tersebut sesuai dengan penelitian Hurtado dan Carter (1997:335), yang menekankan sebaiknya aktivitas tersebut tidak dilandasi kesamaan rasial atau kesukuan karena cenderung menimbulkan iklim permusuhan. Kegiatan kelompok atau berskala besar dapat menghubungkan antarmahasiswa dan memenuhi kebutuhan mereka.

\section{Upaya Pengelola Rumah Susun Mahasis- wa Membentuk Iklim Sosial-Akademik yang Kondusif bagi Mahasiswa}

Litwin dan Stringer (1966) dalam Kundu (2007:100) mengungkapkan bahwa terdapat enam dimensi iklim organisasi, yaitu meliputi (1) struktur, (2) tanggungjawab, (3) penghargaan, (4) resiko dan (5) kehangatan, serta (6) dukungan. Keenam dimensi tersebut nampak sudah disentuh oleh pengelola rumah susun di kedua setting penelitian.

Pola pembinaan di kampus A didesain dengan pendekatan berbasis keagamaan sesuai dengan visi misi lembaganya, sedangkan kampus B cenderung lebih universal karena kedudukannya sebagai universitas negeri. Basis nilai yang melekat pada konsep pembinaan di masing-masing lembaga sangat berpengaruh pada aktivitas atau program yang disusun di masing-masing asrama. Struktur pembinaan di kampus A dimulai dari pengasuh, lalu pembina, kemudian senior residen. Pengasuh yang merupakan seseorang yang ditunjuk oleh kepala rusunawa sebagai pengasuh yang bertanggung jawab pada satu zona rusunawa putra dan zona rusunawa putri. Pola pengasuhan meliputi pembinaan kedisiplinan, kebersihan, busana, keibadahan, dan materi. Materi adalah kegiatan yang diadakan oleh asrama yang kegiatannya wajib dilakukan dan diikuti. Meskipun terdapat perbedaan tentang alur pembinaan di kedua situs penelitian, mahasiswa di kedua lembaga ini samasama menyukai pendekatan pengasuhan yang layaknya orangtua terhadap anakanaknya. Hal menarik yang terungkap, beberapa penghuni rusunawa kampus B mendambakan sistem pengasuhan yang tidak jauh berbeda dengan lingkungan pesantren dimana mereka dulu pernah tinggal dengan berbagai alasan. Alasan yang paling menonjol adalah karena mendambakan sosok orangtua mengingat 
mereka sedang jauh dari orangtua, sekaligus sosok yang disegani dan dapat menjadi tempat mencurahkan permasalahan. Kaitannya dengan penumbuhan kedisiplinan, Semiawan (2009:93) mengungkapkan bahwa disiplin terjadi bila pengaruh diberikan oleh seseorang yang memberikan rasa aman dan tumbuh dari pribadi yang berwibawa serta dicintai, bukan dari orang yang ditakuti dan berkuasa.

Konseppengasuhanyang diidentifikasi oleh para penghuni sebagai pola yang ideal sangat dekat karakteristiknya dengan apa yang dipaparkan Ki Hadjar Dewantara melalui sistem among. Wangid (2009:132133) menjelaskan sistem among sebagai cara yang dipakai dalam sistem pendidikan dengan maksud mewajibkan guru agar menyadari dan mementingkan karakter dan kebutuhan peserta didik dengan tidak melupakan kondisi lingkungan di sekitarnya. Sistem among menitikberatkan pada cara orang dewasa dalam menuntun dan menyokong anakanak mereka ketimbang menggunakan banyak perintah, paksaan dan hukuman. Reinforcement seperti paksaan hanya boleh dilakukan jika jiwa-jiwa muda tersebut tidak dapat menghindarkan diri dari bahaya atau resiko yang bisa menimpanya.

Salah satu aspek dalam pengelolaan rusunawa adalah tahap perekrutan penghuni. Tahapan ini diawali dengan mendiagnosa kesiapan calon penghuni melalui wawancara, karena ada beberapa target output yang harus dicapai penghuni nantinya. Tahap berikutnya adalah masa orientasi. Pengelola menyelenggarakan kegiatan orientasi satu hari penuh yang disusul dengan 1 minggu berikutnya berupapekanorientasitermasuksosialisasi peraturan di asrama. Salah satu peraturan yang disosialisasikan adalah senyum, salam, sapa, tolong, terima kasih, dan maaf.

Pada tahap pembinaan, pengelola asrama aktif mengembangkan komunitas bahasa, penelitian dan seni. Kegiatan komunitas di asrama dilakukan secara terjadwaldan parapenghunidihimbauaktif dan memprioritaskan kegiatan komunitas di asrama daripada kegiatan UKM di universitas. Prioritas kegiatan komunitas di asrama ternyata menimbulkan polemik bagi beberapa mahasiswa yang pada akhirnya memilih mengundurkan diri dari asrama karena ingin aktif di kegiatan UKM universitas dengan berbagai alasan pribadi.

Untuk menilai keberhasilan program pembinaan yang melibatkan para penghuni asrama, pengelola melakukan evaluasi pada aspek kognitif, afektif psikomotorik maupun bahasa. Berdasarkan evaluasi tersebut, terdapat hal menarik yaitu, setiap tahun sekitar $20 \%$ penghuni asrama memilih mengundurkan diri atau keluar dengan berbagaialasan. Alasan yang paling dominan adalah karena mahasiswa kurang mampu menyesuaikan diri dengan target pengelola. Pola pembinaan yang dilakukan di rusunawa A ternyata berdampak baik yaitu banyak alumni asrama yang berhasil dalam akademik dan karir. Hal tersebut merupakan hasil dari pembiasaan manajemen waktu, membangun komitmen yang tinggi, serta rasa tanggungjawab. Hal tersebut sebagaimana disampaikan oleh Semiawan (2009:94) yang menyatakan bahwa semua peraturan kedisiplinan akan menjadi kebiasaan-kebiasaan yang baik bila dalam melaksanakannya memberi kesempatan anak untuk berkembang dan berbuat sesuatu sesuai kemampuannya, bahkan akan berkembang menjadi disiplin diri (self discipline) bila peraturan itu dipegang secara konsisten.

Struktur pembinaan di rusunawa B dimulai dari ketua asrama putra dan asrama putri sebagai pembina, lalu sekretaris harian yang berfungsi sebagai pengasuh asrama yang bergantian setiap harinya, kemudian pengasuh mahasiswa yang dipanggil "Pak Lurah" untuk asrama putra, dan "Bu Lurah" untuk asrama putri. Untuk menciptakan suasana yang tertib 
dan kondusif, pengelola asrama membuat peraturan yang disosialisasikan pada para penghuni di saat masa orientasi atau pembekalan yang mencakup kewajiban, hak, larangan, jam kunjung tamu, jam belajar, dan sanksi bagi yang melanggar. Peraturan yang dibuat tersebut bersifat mengikat dan konsekuensi bagi penghuni yang melanggar. Berkenaan dengan sosialisasi aturan, hal tersebut dilakukan secara terstruktur oleh pengelola di awal penghuni tiba di asrama. Tidak ada seleksi perekrutan penghuni asrama, karena mahasiswa baru wajib tinggal di asrama mahasiswa. Permasalahan yang muncul adalah ada sebagian mahasiswa yang tiba terlambat masuk asrama karena keterlambatan pemerintah daerah mengirim mahasiswanya. Akibatnya, sebagian mahasiswa kurang memahami aturan secara komprehensif dan kurang mengenal para pengasuh walaupun peraturan asrama sesungguhnya telah dipasang di setiap lorong lantai gedung.

Pola pembinaan lainnya adalah dengan melibatkan penghuni dalam berbagai kegiatan sosial dan akademik dalam komunitas kegiatan asrama. Pola pembinaan dengan pelibatan penghuni dalam komunitas kegiatan asrama tersebut sejalan dengan penelitian Hurtado dan Carter (1997) bahwa sejauhmana mahasiswa terintegrasi pada situasi sosial dan akademik di sebuah lingkungan dapat diukur dari tingkat rasa memiliki. Kegiatan-kegiatan yang dilaksanakan pengelola asrama dengan melibatkan para penghuninya dirasa penting untuk menggali rasa memiliki tersebut. Aktivitasaktivitas kebersamaan dapat memupuk sense of belonging di antara mahasiswa.

Pola pengasuhan di asrama dalam pembentukan iklim sosial akademik selanjutnya adalah sejauhmana pengelola mengupayakan interaksi sosial berjalan dengan baik di lingkungan asrama. Interaksi sosial tercipta dalam bentuk rasa memiliki, rasa tanggung jawab, dan kebersamaan di antara penghuni asrama.

\section{Aspek-Aspek dalam Model Pengembang- an Iklim Sosial-Akademik di Rumah Susun Mahasiswa}

Perbandingan temuan kedua kasus penelitian dapat dilihat pada Tabel 1 .

Salah satu model yang secara umum menggagas tentang bagaimana terbentuknya iklim di sebuah organisasi dikemukakan oleh Forehand dan Gilmar dalam Kundu (2007: 101) yaitu adanya dimensi ukuran, struktur, kompleksitas sistem, gaya kepemimpinan dan arahan terhadap tujuan. Adapun Campbell dkk dalam Kundu (2007:102) memaparkan adanya empat dimensi dalam iklim organisasi yang terdiri atas (1) otonomi individual, (2) derajat struktur yang menanamkan posisi-posisi, (3) orientasi terhadap penghargaan, dan (4) perhatian, kehangatan dan dukungan. Dari kedua pendapat tersebut dapat disimpulkan bahwa pembentukan iklim organisasi ditentukan oleh pribadi anggota organisasi itu sendiri, sistem dan mekanisme organisasi, kepemimpinan, dan perhatian organisasi terhadap anggota baik material maupun spiritual. Gambaran tentang dimensi tersebut tidak jauh berbeda dengan temuan peneliti dalam penelitian mengenai iklim sosial-akademik di rumah susun mahasiswa ini. Peneliti merumuskan adanya lima aspek yang perlu dikembangkan guna terciptanya iklim rumah susun yang positif baik dari sosial maupun akademik. Aspek-aspek tersebut terdiri dari penghuni, pengasuh, sistem pembinaan, fasilitas dan organisasi.

Berdasarkan temuan dan ulasan hasil penelitian, dirumuskan sebuah skema kerja yang dapat dikembangkan menjadi model di lapangan untuk mengembangkan iklim sosial-akademik di rumah susun mahasiswa (Gambar 2). Skema ini bersifat umum, dan dapat diterapkan secara lentur 


\section{Tabel 1. Perbandingan Temuan Penelitian di Dua Kasus Penelitian}

\begin{tabular}{ll}
\hline No & \multicolumn{1}{c}{ Kasus A } \\
\hline 1 & $\begin{array}{l}\text { Penghuni Beragam dari berbagai daerah bahkan } \\
\text { juga dari luar negeri }\end{array}$ \\
2 & $\begin{array}{l}\text { Penghuni memiliki latar belakang relatif homogen } \\
\text { (beragam latar daerah tapi homogen dalam keyaki- }\end{array}$ \\
nan / agama) & Penghuni masuk secara sukarela
\end{tabular}

4 Penghuni dikelompokkan ke dalam senioritas, digunakan sebagai basis pembinaan

$5 \quad$ Koordinator berjenjang, sampai dengan tingkat lorong/koridor, yang diperankan oleh mahasiswa senior. Terdapat reward kepada mahasiswa senior resident yang menjadi koordinator.

$6 \quad$ Koordinator level paling bawah (senior resident) dipilih melalui seleksi ketat.

8 Alir pembinaan sangat terstruktur

9 Kegiatan padat, dan harus menjadi prioritas semua mahasiswa di luar jam kuliah

10 Belum terdapat jam belajar

11 Kegiatan berfokus pada pengembangan akhlak dan pembiasaan beribadah

121 kamar diisi oleh 2 penghuni

13 Selain di kamar, ruang belajar tersedia di lobi dan luar kamar tepi gedung

14 Ruang publik tersedia di setiap lantai dengan letak terpusat di tengah

15 Desain bangunan cross block

16 Letak asrama putra dan putri berjauhan

17 Memiliki visi dan misi:

Visi: menjadi ruang pembelajaran yang berkualitas bagi mahasiswa agar menjadi sarjana yang berkarakter, mampu mengembangkan diri dan menjadi kader pembimpin Islam masa depan Misi:

a. Mengadakan pendidikan kepribadian kepada mahasiwa dengan cara meningkatkan pemahaman dan pengamalan Islam yang berkemajuan

b. Meningkatkan ketrampilan mahasiswa dalam berkomunikasi bahasa Inggris dan Arab

18 Kepala pengelola asrama merupakan dosen dibantu staf/ pegawai administrasi, berada di bawah koordinasi rektorat

19 Peraturan asrama berbasis pada nilai-nilai keagamaan

Latar belakang penghuni sangat heterogen (beragam latar daerah dan heterogen dalam keyakinan / agama)

Penghuni masuk sebagian secara sukarela dan sebagian disebabkan kewajiban karena program pendidikan terintegrasi dengan program asrama

Penghuni dikelompokkan sesuai dengan program pendidikan yang diikuti; PPGT, SM3T, regular, digunakan sebagai basis sasaran kegiatan/pembinaan Koordinator masih sebatas ketua asrama atau mahasiswa yang "dituakan" oleh mahasiswa penguhuni lain yang disebut "Pak lurah" dan "Bu Lurah", dan bersifat sukarela.

Koordinator level paling bawah dipilih melalui penunjukan oleh pengelola

Alir pembinaan kurang terstruktur

Kegiatan relatif padat khususnya pada mahasiswa dengan program pendidikan tertentu

Terdapat jam belajar

Kegiatan berfokus pada pengembangan bakat minat namun juga sudah diiringi pengembangan rohani serta karakter

1 kamar diisi oleh 3 penghuni

Selain di kamar, ruang belajar tersedia di lantai dasar

Ruang publik tersedia di setiap lantai dengan letak tidak terpusat (ada dua ruang, dengan letak berseberangan)

Desain bangunan twin block

Letak asrama putra dan putri berdampingan

Memiliki visi dan misi:

Visi: mewujudkan mahasiswan yang cerdas spiritual, sosial, dan intektual

Misi:

a. Menyelenggarakan kehidupan penghuni rusunawa yang agamis

b. Mengarahkan mahasiswa agar mempunyai rasa empati, simpati, toleransi, kerjasama, sosial

c. Membentuk mahasiswa supaya dalam berbicara, bertindak, berpikir dapat dipertanggungjawabkan

Kepala pengelola asrama merupakan dosen dibantu staf/ pegawai administrasi, berada dibawah koordinasi rektorat

Peraturan asrama berbasis pada nilai-nilai universal 


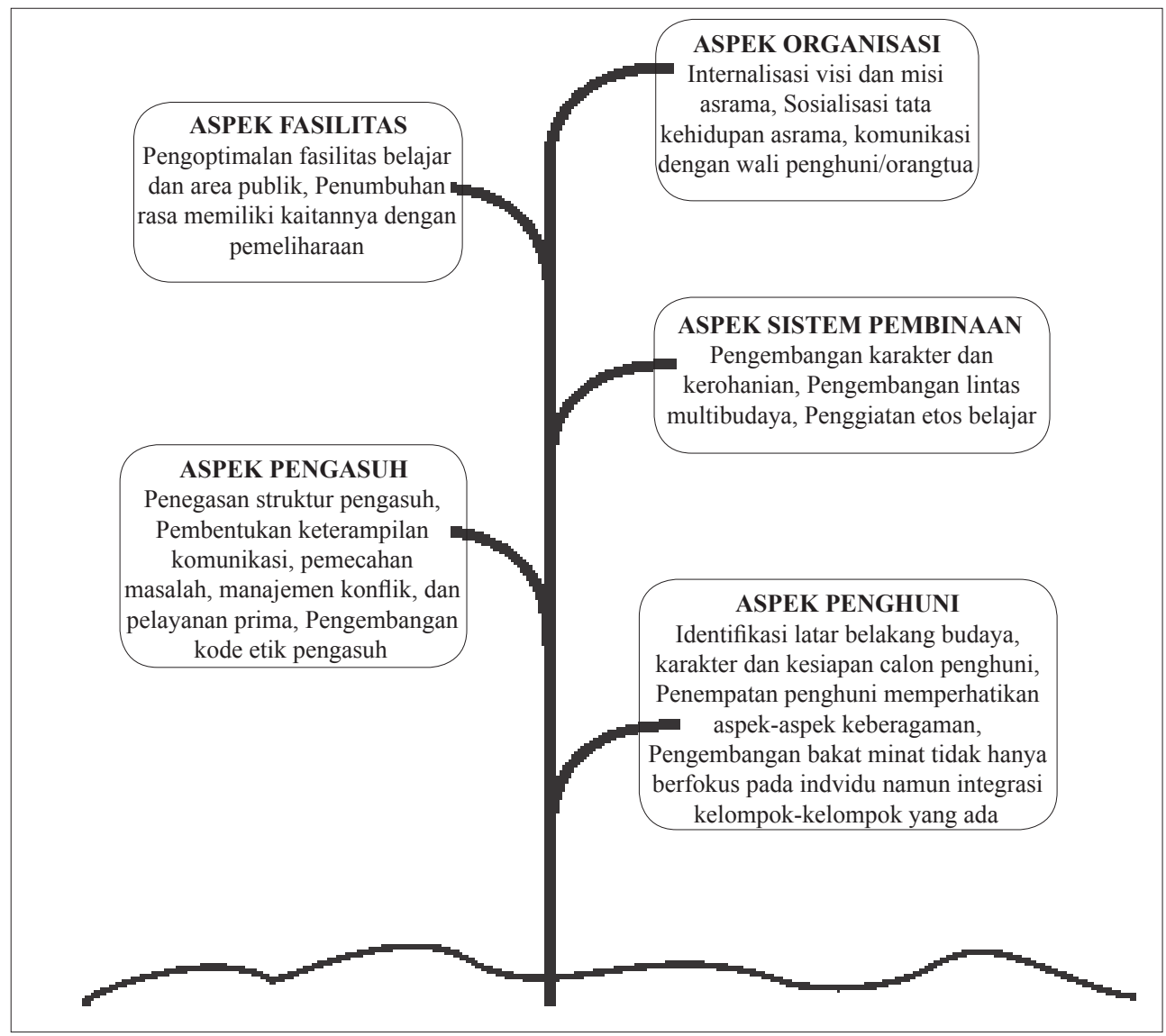

Gambar 2. Aspek-Aspek Tinjauan Pengembangan Iklim Sosial-Akademik di Asrama/Rumah Susun Mahasiswa

sesuai dengan visi misi penyelenggaraan rumah susun mahasiswa.

Skema prototipe model pembentukan iklim sosial akaemik di rumah susun mahasiswa tersebut dijelaskan sebagai berikut:

\section{Aspek Penghuni}

Langkah pembentukan iklim sosialakademik yang kondusif di rumah susun mahasiswa diawali dengan identifikasi pribadi calon penghuni. Hal yang perlu dimaknai adalah latar belakang budaya, karakter dan juga kesiapan calon penghuni terkait dengan minat atau motivasi masuk asrama. Identifikasi ini memerlukan pendataan, dapat dilakukan melalui pengisian biodata, maupun wawancara.

Pada tahap penempatan lebih memperhatikan unsur keberagaman, seperti latar daerah dan suku, agar terjadi pembauran di antara penghuni. Penempatan tidak hanya terfokus pada kamar, namun juga dapat dari zona koridor atau lantai.

Berikutnya adalah memberikan wadah pengembangan bakat minat yang tidak hanya terfokus pada individu namun mengintegrasikan kelompok-kelompok yang ada melalui komunitas kegiatan. Seperti adanya kelompok bakat minat seni kedaerahan, atau komunitas kegiatan olahraga yang melibatkan penghuni dari kelompok-kelompok atau zona-zona tertentu di rumah susun mahasiswa.

Penghuni juga bisa diberikan ruang berekspresi dalam wadah tulisan seperti bulletin yang dibuat dari dan oleh para penghuni.

\section{Aspek Pengasuh}

Untuk mengoptimalkan peran pengasuh adalah dengan mengembangkan struktur pengasuh yang sesuai dengan 
kebutuhan, dengan melibatkan unsur mahasiswa penghuni sebagai bagian dari struktur pengasuh.

Selanjutnya pengasuh mengembangkan kode etik yang didasarkan pada tugas yang diemban.

Langkah berikutnya yaitu mengembangkan keterampilan pengasuh khususnya pada aspek soft skills, seperti komunikasi, pemecahan masalah, manajemen konflik dan pelayanan prima.

\section{Aspek Sistem Pembinaan}

Dalam aspek sistem pembinaan, hal yang pertama dikembangkan adalah peraturan dan kode etik asrama bagi peng-huni yang mengatur hak dan kewajiban penghuni beserta rewards dan punishment yang mengikat dan disepakati bersama.

Perlu dilakukan pemantapan kegiatan pengembangan karakter dan kerohanian. Dapat dilakukan melalui evaluasi dari materi yang sudah ada, pengembangan materi, dan redesain strategi. Penghuni juga diberikan wawasan kebangsaan terutama tentang multibudaya.

Langkah selanjutnya adalah dengan menggiatkan etos atau budaya belajar dengan dukungan fasilitas dan organisasi. Terdapat banyak alternatif untuk membiasakan penghuni giat belajar, tidak hanya adanya jam belajar namun bisa juga dengan pemberian penghargaan terhadap penghuni dengan prestasi akademik terbaik dengan memperhatikan kesehariannya yang diamati langsung oleh penghuni lainnya.

\section{Aspek Fasilitas}

Hal pertama yang perlu dilakukan adalah dengan mengoptimalkan fasilitas belajar yang sudah ada. Semisal area publik yang kurang diminati dapat ditata kembali agar dapat digunakan penghuni sebagai ruang baca, atau tempat berdiskusi kelompok.
Penambahan fasilitas seperti koleksi bacaan juga perlu agar terbina minat baca yang tinggi di kalangan penghuni.

Selanjutnya yang tidak kalah penting adalah bagaimana menumbuhkan rasa memiliki dan kepedulian terhadap fasilitas yang ada sehingga penghuni senantiasa menjaga kebersihan dan merawat fasilitas yang ada. Dalam hal ini dapat dilakukan melalui pengarahan di masing-masing zona terkecil (seperti koridor sampai kamar), lomba kebersihan kamar atau lantai, dan juga pengarahan tertulis berupa pesan-pesan untuk mengingatkan penghuni betapa pentingnya memelihara fasilitas yang ada.

\section{Aspek Organisasi}

Berbicara mengenai organisasi tidak lepas dari visi dan misi yang diusung. Visi dan misi pengelola rumah susun mahasiswa tidak akan optimal bila tidak diimplementasikan juga oleh para penghuninya. Oleh sebab itu diperlukan internalisasi visi dan misi asrama dengan penguatan terhadap budaya organisasi (semisal 3S: senyum, salam, sapa),dan sosialisasi visi dan misi organisasi beserta tata kehidupan asrama.

Hal lain yang dilakukan adalah dengan menjalin komunikasi dengan wali atau orangtua. Komunikasi ini bisa ditempuh dengan biaya yang lebih terjangkau seperti pengiriman informasi melalui surat atau surat elektronik. Komunikasi ini pada prinsipnya agar orangtua mengetahui tentang hak dan kewajiban putra-putri mereka selama berada di rumah susun mahasiswa sehingga orangtua juga turut memantau perkembangan putra dan putri mereka.

\section{SIMPULAN}

Iklim sosial akademik di kedua situs penelitian secara umum dipersepsikan positif atau baik oleh para penghuninya. Meskipun dengan demikian pada kasus 
kedua ditemukan catatan khusus berkaitan dengan fasilitas, interaksi lintas budaya, dan sistem pembinaan serta pengasuh.

Upaya pengelola rumah susun mahasiswa di kedua situs penelitian telah mengarah pada pembentukan iklim sosial akademik namun masih perlu dipertajam. Upaya yang telah dilakukan di kedua lembaga secara umum terdiri atas: a) Pengembangan visi dan misi penyelenggaraan rumah susun mahasiswa, b) Internalisasi tata kehidupan asrama, c) Pelibatan penghuni dalam kegiatan komunitas asrama baik untuk pengembangan bakat minat maupun sosial akademik, d) Pengembangan karakter atau akhlak, e) Pengoptimalan fasilitas yang men-dukung belajar, f) Mengembangkan interaksi sosial pengelola dan penghuni asrama.

Dari hasil penelitian dapat diidentifikasi aspek-aspek yang menjadi komponen dalam pengembangan iklim sosialakademik di rumah susun mahasiswa, yaitu: a) aspek penghuni, b) aspek pengasuh, c) aspek sistem pembinaan, d) aspek fasilitas, dan e) aspek organisasi.

\section{DAFTAR PUSTAKA}

Bogdan, R.C \& Biklen, S.K. (1998). Qualitative Research Education. Boston: Allyn and Bacon.

Bozick, R. (2007). "Making It Through the FirstYearofCollege:TheRoleofStudents' Economic Resources, Employment, and Living Arrangements". Journal of Sociology of Education, July 2007, 80, 3. P 261-284.

De Araujo, P. \& Murray, J. (2010). "Estimating the E_ects of Dormitory Living on Student Performance. University of Wisconsin-La Crosse". http://papers. ssrn.com/sol3/. Diakses 21 Maret 2013.

Elvia, Y. (2011). "Hubungan antara Kesesakan dengan Intensi Prososial pada Penghuni Rumah Susun". http:// library.gunadarma.ac.id/repository/. Diakses 17 Maret 2013.
Gibson, J.L., Ivancevich, J. M., Donnelly, J.H., \& Konopaske, R. (2004). Organizations: Behavior, Structure, Processes. New York, NY: McGraw-Hill.

Hurtado, S. \& Carter, D.F. (1997). "Effects of College Transition and Perceptions of The Campus Racial Climate on Latino College Students Sense of Belonging." Journal Sociology of Education, Oktober 1997 volume 70 no 4, hal 324-345. http://search.proquest. com/docview/. Diakses pada 10 Maret 2013.

Kundu, K. (2007). "Development of The Conceptual Framework of Organizational Climate". Vidyasagar University Journal of Commerce Vol. 12, March 2007. http://www. vidyasagar.ac.in/journal/Commerce/ vol12/. Diakses pada 10 Oktober 2013.

Owens, R.G. (1995). Organizational Behavior in Education. Boston: Allyn and Bacon.

Rodger, S.C. \& Johnson, Andrew M. (2005). "The Impact of Residence on Freshman Outcomes: Dormitories Versus SuiteStyle Residences". The Canadian Journal of Higher Education, 2005, 35, 3. http://search.proquest.com/ docview/. Diakses 19 Maret 2013.

Semiawan, C.R. (2009). Penerapan Pembelajaran pada Anak. Jakarta: PT Indeks.

Sururi dan Nasihin, S. (2010). Manajemen Peserta Didik. Bandung: Alfabeta.

Sutopo, H.B. (2002). Metode Penelitian Kualitatif: Dasar Teori dan Terapannya dalam Penelitian. Surakarta: Sebelas Maret University Press.

Usman. 2004. Manajemen Pendidikan. Yogyakarta: Pascasarjana UNY.

Wangid, M.N. (2009). "Sistem Among pada Masa Kini: Kajian Konsep dan Praktik Pendidikan". Jurnal Kependidikan, Vol 39, Nomor 2, November 2009, hal. 129-140.

Yin, R.K. 1995. Studi Kasus; Desain dan Metode. Terjemahan M. Djauzi Mudzakir. Jakarta: Raja Grafindo Persada. 